\title{
Evaluation of the fungal activity of Beauveria bassiana, Metarhizium anisopliae and Paecilomyces lilacinus as biocontrol agents against root-knot nematode, Meloidogyne incognita on cowpea
}

\author{
Mahmoud M. A. Youssef ${ }^{*}$ (D), Wafaa M. A. El-Nagdi ${ }^{1}$ and Dalia E. M. Lotfy ${ }^{2}$
}

\begin{abstract}
Background: In the current years, nematotoxic or antagonistic compounds for example, toxins, enzymes, or compounds derived from the metabolites of fungal culture filtrates have greatly increased.

Objective: This research was designed to evaluate two fungi, Beauveria bassiana and Metarhizium anisopliae, commonly used only as bio-insecticides in Egypt for their nematicidal potential compared to Paecilomyces lilacinus, one of the most important fungi parasitizing on eggs of root-knot nematode, Meloidogyne incognita.

Results: The tested fungi either as filtrate or spore affected egg hatching and survival of second stage juveniles at different degrees according to fungal filtrate dilution and spore concentration and exposure period under in vitro study. Under screen house conditions, the tested fungi as filtrates or spores were used to control root-knot nematode on cowpea. The overtopped significant results were gained with $P$. lilacinus filtrate at standard dilution and recorded the highest mean overall percentages nematode reduction (84.5\%). The second rank was obtained by B. bassiana culture filtrate, where it significantly reduced all nematode numbers with a mean of $81.1 \%$ at standard dilution. M. anisopliae caused $78.5 \%$ as a mean percentages nematode reduction followed by other dilutions and untreated check. When using spore concentrations, the overtopped significant results were gained with $P$. lilacinus at the highest spore concentration $\left(1 \times 10^{8}\right)$ and recorded the highest mean percentages nematode reduction (85.3\%). The second rank was obtained by M. anisopliae, where it reduced all nematode numbers as an average of 83.6\%. B. bassiana caused $77.1 \%$ as a mean percentages nematode reduction at the highest spore concentration. At all cases, all treatments significantly promoted plant growth and yield criteria and these increases were positively proportional to the filtrate dilution or spore concentration higher than the untreated plants.

Conclusions: It can be concluded that B. bassiana, M. Anisopliae, and P. lilacinus as antagonistic fungi proved to be efficient against root-knot nematode, incognita infecting cowpea as they reduced nematode criteria which subsequently improved plant growth and yield of cowpea.
\end{abstract}

Keywords: Beauveria bassiana, Cowpea, Fungal bioagents, In vitro, In vivo, Meloidogyne incognita, Metarhizium anisopliae, Paecilomyces lilacinus

\footnotetext{
*Correspondence: myoussef_2003@yahoo.com

'Department of Plant Pathology, Nematology Lab., National Research Centre,

Dokki, Cairo 12622, Egypt

Full list of author information is available at the end of the article
}

\section{Springer Open}

(c) The Author(s). 2020 Open Access This article is licensed under a Creative Commons Attribution 4.0 International License, which permits use, sharing, adaptation, distribution and reproduction in any medium or format, as long as you give appropriate credit to the original author(s) and the source, provide a link to the Creative Commons licence, and indicate if changes were made. The images or other third party material in this article are included in the article's Creative Commons licence, unless indicated otherwise in a credit line to the material. If material is not included in the article's Creative Commons licence and your intended use is not permitted by statutory regulation or exceeds the permitted use, you will need to obtain permission directly from the copyright holder. To view a copy of this licence, visit http://creativecommons.org/licenses/by/4.0/. 


\section{Background}

Biological control of nematodes is one of the most important approaches in nematode management directed towards a sustainable agriculture (Mokhtari et al. 2009). Some soil inhabiting fungi have ability to controlling the nematodes (Tian et al. 2007). Endophytic entomopathogens are known to colonize several horticultural and agronomic crops, providing protection from herbivore damage and also regulating insect populations (Vianna et al. 2018). As fungi cohabit together with plant-parasitic nematodes in the rhizosphere, their toxic metabolites may keep a low level of nematode populations (Kerry 2000). The search for nematotoxic or antagonistic compounds in fungal culture filtrates has greatly increased in the last years, due to the toxins, enzymes, or compounds derived from their metabolites (Ciancio 1995; Liu et al. 2008). Among these fungi, green muscardine, Metarhizium anisopliae, is considered a soil dwelling fungus with entomopathogenic characteristics. The effect of this fungus against reniform nematode, Rotylenchulus reniformis, was studied (Tribhuvaneshwar Sharma and Bhargava 2008). Biocontrol potential of $M$. anisopliae against some species of root-knot nematodes was studied by some investigators (Jahanbazian et al. 2014; Khosrawi et al. 2014; Jahanbazian et al. 2015). Ghayedi and Abdollahi (2013) purified the isolated fungus, Beauveria bassiana, and showed the biocontrol potential of the isolate on Heterodera avenae, with $47.1 \%$ of larval mortality and has a suppressive action on nematodes of the genus Meloidogyne spp. (Bekanayake and Jayasundar 1994; Caroppo et al. 1990). B. bassiana may have more than a single bioactive metabolite with nematicidal activity, and each metabolite may act on a different site. It was shown that $B$. bassiana produces beauvericin and oosporin, and beauvericin proved to have nematicidal activity against M. incognita (Hamil et al. 1969; Suzuki et al. 1977; Anke et al. 1995). Little parasitism of nematode eggs by B. bassiana was shown by Chen et al. (1996), but it inhibited hatching of Heterodera glycines. As reported by Cayrol et al. (1992), that egg-parasitic fungi can infect nematodes, destroying their eggs. Most of these fungi act as saprophytes, and can secondarily invade already-dead eggs. Among these fungi, P. lilacinus which is considered probably the most effective egg parasites and has been shown to successfully control root knot nematodes, $M$. javanica and $M$. incognita, on tomato, eggplant, potato, and other vegetable crops (Cayrol et al. 1989; Aboul-Eid and Youssef 1998; Goswami and Mittal 2004; Goswami et al. 2006; Haseeb and Kumar 2006). Nearly, no work was done on the effect of two fungi, $B$. bassiana and $M$. anisopliae, on root knot nematode or other plant-parasitic nematodes in Egypt.
Therefore, this research was designed to evaluate two fungi, B. bassiana and M. anisopliae, commonly used only as bio-insecticides for their nematicidal potentials against root-knot nematode, $M$. incognita, on cowpea compared to $P$. lilacinus fungus, under screen house conditions.

\section{Methods}

Pure culture of root-knot nematode inoculum

$M$. incognita was the tested species of root knot nematode, identified from nematode adult female on the basis of the morphological characteristics of the female perineal pattern (Taylor and Sasser 1978). Pure culture of $M$. incognita was reared on eggplant cv. Ice in a screen house of Nematology Lab., Plant Pathology Department, National Research Centre at $30 \pm 5^{\circ} \mathrm{C}$ by using a single egg mass of this nematode. Newly hatched second stage juveniles $\left(\mathrm{J}_{2} \mathrm{~s}\right)$ and eggs were used as inocula.

\section{Fungus culture}

Isolates of $B$. bassiana, $M$. anisopliae, and P. lilacinus were obtained from Assiut University, Mycological Center, Faculty of Science. The isolates were cultured on Sabouraud dextrose yeast agar (SDYA) medium (Sabouraud 1892) which contained $40 \mathrm{~g}$ glucose, $20 \mathrm{~g}$ peptone, $20 \mathrm{~g}$ agar, and $2 \mathrm{~g}$ yeast extract in $1000 \mathrm{ml}$ of distilled water in flasks which were autoclaved at $21{ }^{\circ} \mathrm{C}$ for $15-20 \mathrm{~min}$.

\section{Preparation of spore suspension}

Fungal cultures grown on Sabouraud dextrose yeast agar (SDYA) medium were incubated at $25 \pm 2{ }^{\circ} \mathrm{C}$ in darkness for 14 days. Conidial medium suspensions were prepared by scraping cultures with a sterile objective glass and transferred to $10 \mathrm{ml}$ of sterile water containing $0.05 \%$ Tween 80 in a laminar flow chamber. The conidia were harvested by scraping the surface of the culture with inoculation needle. The mixture (spores+ hyphae) was stirred for $10 \mathrm{~min}$ and the hyphae were removed by filtering the mixture through fine mesh sieve. The conidial concentration of final suspension was determined $\left(1 \times 10^{8}\right.$ viable conidia) by direct count using hemocytometer. Serial dilutions were prepared in distilled water containing $0.1 \%$ Tween 80 and preserved at $5{ }^{\circ} \mathrm{C}$ until used. In vitro nematode tests were applied to evaluate efficacy of fungal spores against root knot nematode, $M$. incognita eggs. A volume of the adjustable concentrations $\left(1 \times 10^{6}, 1 \times 10^{7}\right.$, and $\left.1 \times 10^{8}\right)$ viable conidia were directly applied to the eggs.

\section{Preparation of supernatant}

The filtrates of B. bassiana, M. anisopliae, and P. lilacinus were produced on broth semi-synthetic Sabouraud dextrose yeast. The medium was prepared and adjusted 
at $\mathrm{PH}$ (5.5-6.6). After sterilization, flasks were inoculated with the fungal species and incubated for 2 weeks at $25{ }^{\circ} \mathrm{C}$ and $50-60 \% \mathrm{Rh}$. At the end of the incubation period, the supernatant was separated from the mats by filtration through Whatman filter paper No.1 under aseptic conditions and the supernatant at different dilutions [S (Standard), $S / 2$ and $S /$ ] were used for bioassay against nematodes (Barker 1985).

\section{Laboratory tests}

In vitro test was carried out to determine the effect of culture filtrates of the studied fungi, B. bassiana, M. anisopliae, and P. lilacinus, at dilutions, $\mathrm{S}, \mathrm{S} / 2$, and $\mathrm{S} / 4 M$. incognita egg hatching from infected tomato roots. Eggs were extracted by Clorox ( $\mathrm{NaOCl} 1.0 \%$.), then the suspension was poured onto a 500 mesh sieve and washed by excess tap water to remove $\mathrm{NaOCl}$ (Hussey and Barker 1973). Then, extracted eggs were transferred to into clean beaker with sterilized water. One milliliter of distilled water containing 300 nematode eggs was put in plastic capsule with $9 \mathrm{ml}$ of each fungal filtrate dilution. Control treatment was made by adding $1 \mathrm{ml}$ of distilled water containing 300 nematode eggs to 9-ml distilled water as comparison. There were 5 replicates for each treatment.

Also, in vitro test was applied to evaluate efficacy of three conidial spore concentrations from B. bassiana, $M$. aniisopliae, and P. lilacinus against root knot nematode, M. incognita eggs. Concentrations of $1 \times 10^{6}, 1 \times 10^{7}$, and $1 \times 10^{8}$ viable conidia were directly applied to eggs by adding $1 \mathrm{ml}$ distilled water containing 300 eggs in plastic capsule with $9 \mathrm{ml}$ of each fungal spore's suspension concentration. Equal number of eggs was also transferred to separate plastic capsule containing 9-ml distilled water to serve as control.

Observations on the number of non-hatched eggs by light microscope were made 24, 48, 72, and $96 \mathrm{~h}$ after treatment. Data on non-hatched eggs were converted to the percentages of egg inhibition at each period and dilution according to Abbott's formula (Abbott 1925) as follows:

$$
\text { Egg inhibition }(\%)=(m-n) /(100-n) \times 100
$$

where $m$ and $n$ stand for the percentages of non-hatched eggs in the treatment and control, respectively. Net percentage egg inhibition was calculated by subtracting percentage of recovery (hatched eggs in distilled water) from the percentage inhibition after $96 \mathrm{~h}$.

\section{Mortality of second stage juveniles $\left(\mathrm{J}_{2}\right)$}

For determining the effect of fungal filtrates of $B$. bassiana, $M$. anisopliae, and P. lilacinus on second stage juvenile mortality $\left(\mathrm{J}_{2}\right)$ of $M$. incognita, the number of $\mathrm{J}_{2}$ in the soil per pot was extracted using a sieving and decanting technique (Barker 1985) and counted. For extraction of second stage juveniles $\left(\mathrm{J}_{2}\right)$ of $M$. incognita from roots, galled eggplant roots with egg masses per plant were washed thoroughly with tap water to avoid debris and cut into small pieces. Then, they were placed in plastic capsule containing sufficient water, covered to avoid loss of water by evaporation, and collected every $24 \mathrm{~h}$ (Young 1954). The same procedures were carried when $1 \mathrm{ml}$ of distilled water containing $200 \mathrm{~J}_{2}$ was added to $9 \mathrm{ml}$ of filtrate of each fungus. Control treatment was made by adding $9 \mathrm{ml}$ of distilled water to $1 \mathrm{ml}$ of nematode suspension containing the same number of nematodes.

Number of dead and alive juveniles per each treatment was determined under light microscope 24,48 , and $72 \mathrm{~h}$ after treatment. The $\mathrm{J}_{2}$ were considered dead when they did not move when probing with a fine needle. Data on nematode mortality were converted to the percentages of nematode mortality according to Abbott's formula (Abbott 1925) as follows:

$$
\text { Juvenile mortality }(\%)=(m-n) /(100-n) \times 100
$$

where $m$ and $n$ are for the percentages of dead juveniles in the treatment and control, respectively. Net percentage of mortality was calculated by subtracting percentage of nematode recovery in distilled water from the percentage of mortality after $72 \mathrm{~h}$.

\section{Screen house experiments Pot experiment design}

The experiment was carried out in pots in screen house of Plant Pathology Department, National Research Centre (NRC). Seeds of cowpea (Vigna unguiculata (L.) Walp.) cv. Baladi were sown in each pot in April 5, 2018 in pots $(20-\mathrm{cm}$ diameter) containing $2 \mathrm{~kg}$ of solarized sandy loamy soil. Each pot was inoculated with 2000 newly hatched juveniles $\left(\mathrm{J}_{2}\right)+1000$ eggs of $M$. incognita in April 19, 2018. This inoculum was made in four holes made around the plant. At the same time of nematode inoculation, cowpea plants were treated with the tested three cultural filtrates of $B$. bassiana, M. anisopliae, and $P$. lilacinus. These fungi were tested at dilutions, $\mathrm{S}, \mathrm{S} / 2$, and $\mathrm{S} / 4$ at the rate of $10 \mathrm{ml}$ per pot from each dilution in four holes around the plant and nematode only with liquid medium (control) used as untreated check. Pots were arranged in a completely randomized design with 5 replicates for each treatment on a bench under screen house conditions maintained at $30 \pm 5^{\circ} \mathrm{C}$. Then, the plants were irrigated as needed.

After 3 months of nematode inoculation (harvest stage of cowpea plant) in July 2018, plants of cowpea were carefully uprooted and roots were washed thoroughly 
with running tap water to avoid debris. Then, roots were cut into two halves. Numbers of $\mathrm{J}_{2}$ in soil and roots, egg masses, as well as number of galls per plant were counted in one half of roots. The number of $\mathrm{J}_{2}$ in the soil per pot was extracted using a sieving and decanting technique (Barker 1985) and counted. Then, the second half of roots was incubated in tap water by incubation method (Young 1954) to help hatching $\mathrm{J}_{2}$ from egg masses. All $\mathrm{J}_{2}$ numbers of nematodes were counted under a light microscope.

At the same time, plant growth criteria of cowpea including shoot length $(\mathrm{cm})$, fresh and dry shoot weights (g), and fresh and dry weights of roots (g) were recorded. Also, number and weight of pods (g) were recorded.

Also, in the second experiment, the same procedures were applied except that three concentrations of $1 \times 10^{8}$, $1 \times 10^{7}$, and $1 \times 10^{6}$ spores of the tested fungi at the rate of $10 \mathrm{ml}$ per each concentration were tested. Mean percentages of nematode reduction, plant growth, and yield increases were calculated by dividing sum percentages of all parameters of each treatment/number of these parameters. This measurement was used to compare among treatments within all groups.

\section{Statistical analysis}

This experiment has been carried out according to analysis of variance (ANOVA) procedures. Duncan's multiple range test as reported by Snedecor and Cochran (1989) was used for comparing among treatments at 5\% level of probability. This was done by Computer Statistical Package (COSTAT) User Manual Version 3.03, Barkley Co.

\section{Results}

\section{Laboratory studies}

Effect of fungal culture filtrates on egg hatching

Data in Table 1 illustrated that culture filtrates of $B$. bassiana, M. anisopliae, and P. lilacinus inhibited
M. incognita egg hatching at each exposure period (24, 48,72 , and $96 \mathrm{~h}$ ) compared to those of control. Generally, the percentages of hatching gradually increased with time and concentration of filtrate. In other words, the percentages of hatching were maximum at $96 \mathrm{~h}$, but after $24 \mathrm{~h}$, no egg hatching occurred. It was noticed that the highest percentage of net egg inhibition (90.0\%) was achieved at S dilution of fungi, B. bassiana and $M$. anisopliae, followed by $77.5 \%$ mortality occurred by $M$. aniisopliae at $\mathrm{S} / 2$ dilution and $77.0 \%$ at $\mathrm{S} / 4,75.0 \%$ mortality occurred by $P$. lilacinus at $\mathrm{S}$ dilution. The rest dilutions of each fungus recorded less percentages of egg inhibition, whereas the least percentage of egg inhibition was recorded by $\mathrm{S} / 4$ dilution.

\section{Effect of fungal spores on egg hatching}

Data in Table 2 illustrated that spore concentrations of B. bassiana, $M$. anisopliae, and P. lilacinus inhibited $M$. incognita egg hatching at each exposure period (24, 48, 72 , and $96 \mathrm{~h}$ ) compared to those of control. Generally, the percentages of hatching gradually increased with time and concentration of spores. In other words, the percentages of hatching were maximum at $96 \mathrm{~h}$, but after $24 \mathrm{~h}$, no egg hatching occurred. It was noticed that the highest percentage of net egg inhibition (42.5\%) was achieved at $\mathrm{S}$ dilution of spores of fungus, P. lilacinus, followed by $37.5 \%$ occurred by $M$. anisopliae at S dilution, and $35.0 \%$ by $B$. bassiana at $\mathrm{S}$ dilution. The rest of dilutions of each fungus recorded less percentages of egg inhibition, whereas the least percentage of egg inhibition was recorded by $\mathrm{S} / 4$ dilution.

\section{Effect of fungal culture filtrates on mortality of nematode juveniles}

Data in Table 3 illustrated that culture filtrates of $B$. bassiana, $M$. anisopliae, and P. lilacinus inhibited $M$. incognita juveniles at each exposure period (24, 48, and $72 \mathrm{~h}$ )

Table 1 Percentages of egg inhibition of root knot nematode, Meloidogyne incognita, as influenced by three culture filtrate dilutions from Beauveria bassiana, Metarhiziam aniisopliae, and Paecilomyces lilacinus after 24, 48, 72, and $96 \mathrm{~h}$ exposure

\begin{tabular}{|c|c|c|c|c|c|c|c|}
\hline \multirow[t]{2}{*}{ Treatments } & \multirow[t]{2}{*}{ Dilution } & \multicolumn{4}{|c|}{ \% egg inhibition } & \multirow{2}{*}{$\begin{array}{l}\% \\
\text { recovery }\end{array}$} & \multirow{2}{*}{$\begin{array}{l}\% \text { net } \\
\text { inhibition }\end{array}$} \\
\hline & & $24 \mathrm{~h}$ & $48 \mathrm{~h}$ & $72 \mathrm{~h}$ & $96 \mathrm{~h}$ & & \\
\hline \multirow[t]{3}{*}{ Beauveria bassiana } & S & 00.0 & 77.5 & 90.0 & 91.7 & 1.7 & 90.0 \\
\hline & $\mathrm{S} / 2$ & 00.0 & 75.0 & 80.0 & 85.6 & 10.6 & 75.0 \\
\hline & $\mathrm{S} / 4$ & 00.0 & 62.5 & 67.5 & 70.0 & 5.0 & 65.0 \\
\hline \multirow[t]{3}{*}{ Metarhiziam aniisopliae } & S & 00.0 & 82.5 & 92.5 & 95.0 & 5.0 & 90.0 \\
\hline & $\mathrm{S} / 2$ & 00.0 & 80.0 & 85.0 & 87.5 & 10.0 & 77.5 \\
\hline & $\mathrm{S} / 4$ & 00.0 & 75.0 & 77.5 & 80.0 & 3.0 & 77.0 \\
\hline \multirow[t]{3}{*}{ Paecilomyces lilacinus } & $S$ & 00.0 & 70.0 & 80.0 & 85.0 & 10.0 & 75.0 \\
\hline & $\mathrm{S} / 2$ & 00.0 & 65.0 & 67.0 & 72.5 & 2.5 & 70.0 \\
\hline & $\mathrm{S} / 4$ & 00.0 & 55.0 & 62.5 & 65.0 & 00.0 & 65.0 \\
\hline Distilled water (control) & - & 00.0 & 00.0 & 00.0 & 00.0 & 00.0 & 00.0 \\
\hline
\end{tabular}


Table 2 Percentages of egg inhibition of root-knot nematode, Meloidogyne incognita, as influenced by three spore concentrations from Beauveria bassiana, Metarhiziam aniisopliae, and Paecilomyces lilacinus after 24, 48, 72, and $96 \mathrm{~h}$ exposure

\begin{tabular}{|c|c|c|c|c|c|c|c|}
\hline \multirow[t]{2}{*}{ Treatments } & \multirow[t]{2}{*}{ Concentration } & \multicolumn{4}{|c|}{$\%$ egg inhibition } & \multirow{2}{*}{$\begin{array}{l}\% \\
\text { recovery }\end{array}$} & \multirow{2}{*}{$\begin{array}{l}\% \text { net } \\
\text { inhibition }\end{array}$} \\
\hline & & $24 \mathrm{~h}$ & $48 \mathrm{~h}$ & $72 \mathrm{~h}$ & $96 \mathrm{~h}$ & & \\
\hline \multirow[t]{3}{*}{ Beauveria bassiana } & $1 \times 10^{8}$ & 0 & 60.0 & 61.5 & 63.0 & 28.0 & 35.0 \\
\hline & $1 \times 10^{7}$ & 0 & 47.0 & 49.0 & 50.0 & 24.5 & 25.5 \\
\hline & $1 \times 10^{6}$ & 0 & 40.0 & 42.5 & 44.0 & 26.0 & 18.0 \\
\hline \multirow[t]{3}{*}{ Metarhiziam aniisopliae } & $1 \times 10^{8}$ & 0 & 62.5 & 65.0 & 67.0 & 29.5 & 37.5 \\
\hline & $1 \times 10^{7}$ & 0 & 57.5 & 60.5 & 62.5 & 30.5 & 22.0 \\
\hline & $1 \times 10^{6}$ & 0 & 45.0 & 47.5 & 50.0 & 30.0 & 20.0 \\
\hline \multirow[t]{3}{*}{ Paecilomyces lilacinus } & $1 \times 10^{8}$ & 0 & 65.0 & 72.5 & 80.0 & 37.5 & 42.5 \\
\hline & $1 \times 10^{7}$ & 0 & 57.0 & 60.0 & 67.0 & 32.0 & 35.0 \\
\hline & $1 \times 10^{6}$ & 0 & 47.5 & 50.0 & 72.0 & 44.5 & 27.5 \\
\hline Distilled water (control) & - & 0 & 00.0 & 00.0 & 00.0 & 00.0 & 00.0 \\
\hline
\end{tabular}

compared to those of control. Generally, the percentages of mortality gradually increased with time and dilution of filtrate. In other words, the percentages of mortality were maximum at $96 \mathrm{~h}$. It was noticed that the highest percentage net juvenile mortality $(100.0 \%)$ was achieved at S dilution of fungus, $M$. aniisopliae, followed by 97 and $95 \%$ occurred by the same fungus at $S / 2$ and $S / 4$, respectively. This followed by fungus $P$. lilacinus caused $76 \%$ mortality at $\mathrm{S}$ dilution. The rest of dilutions of each fungus tested recorded less percentages of egg inhibition, whereas the least percentage of egg inhibition was recorded by $\mathrm{S} / 4$ dilution.

\section{Screen house experiment}

\section{Effect of the tested fungal culture filtrates on root-knot} nematode

Tables 4 and 5 show that three culture filtrates from $B$. bassiana, M. anisopliae, and P. lilacinus were selected

Table 3 Effects of three culture filtrate dilutions from Beauveria bassiana, Metarhiziam aniisopliae and Paecilomyces lilacinus on the mortality of second-stage juveniles of Meloidogyne incognita under in vitro test

\begin{tabular}{llllllll}
\hline Treatments & Dilution & \multicolumn{3}{c}{$\%$ mortality } & & $\%$ & $\%$ net \\
\cline { 2 - 5 } & & $24 \mathrm{~h}$ & $48 \mathrm{~h}$ & $72 \mathrm{~h}$ & & recovery & mortality \\
\hline Beauveria bassiana & $\mathrm{S}$ & 89 & 94 & 95 & 25 & 70 \\
& $\mathrm{~S} / 2$ & 85 & 91 & 95 & 20 & 75 \\
& $\mathrm{~S} / 4$ & 78 & 80 & 82 & 17 & 65 \\
Metarhiziam aniisopliae & $\mathrm{S}$ & 94 & 98 & 100 & 00 & 100 \\
& $\mathrm{~S} / 2$ & 91 & 95 & 97 & 00 & 97 \\
& $\mathrm{~S} / 4$ & 82 & 90 & 95 & 00 & 95 \\
Paecilomyces lilacinus & $\mathrm{S}$ & 91 & 93 & 96 & 20 & 76 \\
& $\mathrm{~S} / 2$ & 87 & 90 & 92 & 38 & 54 \\
& $\mathrm{~S} / 4$ & 64 & 68 & 88 & 62 & 26 \\
Distilled water (control) & - & 00 & 00 & 00 & 00 & 00 \\
\hline
\end{tabular}

for their efficacy to control M. incognita infecting cowpea. Number of nematode juveniles in soil and roots, egg masses, as well as number of galls and number of bacterial nodules were significantly increased compared to untreated check (Table 4). In general, on the basis of mean total percentages nematode reduction, data in Table 5 indicated that all chosen fungal culture filtrates had suppressed the previous criteria according to fungus and filtrate dilution compared to untreated check. The overtopped significant results were gained with $P$. lilica$n u s$ at $\mathrm{S}$ dilution which recorded the highest mean nematode reduction $(84.5 \%)$ with the highest reduction of number of egg masses (84.2\%) and higher percentage reduction in soil $(86.4 \%)$ and roots $(82.9 \%)$. The second rank was obtained by $B$. bassiana culture filtrate, where it significantly reduced all nematode numbers as a mean of $81.1 \%$ at $\mathrm{S}$ dilution with the highest percentages reduction of number of juveniles in roots $(85.7 \%$.) and number of second stage juveniles in soil (86.4\%) at the same dilution. M. anisopliae caused $78.5 \%$ as a mean percentage of nematode reduction followed by other dilutions and untreated check.

Also, the percentages of reductions of galls were significantly reduced by $77.3 \%$ caused by P. lilacinus at S dilution followed by B. bassiana (75.8\%) and M. aniisopliae $(69.7 \%)$ at the same dilution compared to other treatments. On the other hand, control treatment (untreated infected plants) registered the highest numbers of reproductive parameters of nematode and galls of root knot nematode.

Number of bacterial nodules significantly increased by $72.4 \%$ and $65.5 \%$ caused by B. bassiana at $\mathrm{S}$ and $\mathrm{S} / 2$ dilutions, respectively. These were followed by 62.1 and $51.7 \%$ occurred by $P$. lilacinus at $\mathrm{S}$ and $\mathrm{S} / 2$, respectively. Percentages of increases 44.8 and $34.5 \%$ were achieved by $M$. anisopliae at $\mathrm{S}$ and $\mathrm{S} / 2$ dilutions, respectively. $\mathrm{S} / 4$ recorded the least ones. 
Table 4 Number of the root-knot nematode, Meloidogyne incognita infecting cowpea, number of gall and number of bacterial nodules as affected by three culture filtrates from Beauveria bassiana, Metarhiziam aniisopliae, and Paecilomyces lilacinus

\begin{tabular}{|c|c|c|c|c|c|c|}
\hline \multirow[t]{2}{*}{ Treatments } & \multirow[t]{2}{*}{ Dilution } & \multicolumn{3}{|c|}{ Mean no. of reproductive parameters of nematode } & \multirow{2}{*}{$\begin{array}{l}\text { Mean } \\
\text { no. of } \\
\text { galls/ } \\
\text { root } \\
\text { system }\end{array}$} & \multirow{2}{*}{$\begin{array}{l}\text { Mean } \\
\text { no. of } \\
\text { bacterial } \\
\text { nodules/ } \\
\text { root } \\
\text { system }\end{array}$} \\
\hline & & $\mathrm{J}_{2} \mathrm{~s}$ in soil/pot & $\mathrm{J}_{2} \mathrm{~s}$ in roots/root system & Egg masses/root system & & \\
\hline \multirow[t]{3}{*}{ Beauveria bassiana } & S & 1500ef & $50 e$ & $11 \mathrm{ef}$ & 16de & $50 a$ \\
\hline & $S / 2$ & $2200 \mathrm{~cd}$ & $60 e$ & 13def & 18de & $48 a b$ \\
\hline & $S / 4$ & $4000 \mathrm{~b}$ & $110 c$ & $18 \mathrm{bc}$ & $26 c$ & $36 e$ \\
\hline \multirow[t]{3}{*}{ Metarhiziam aniisopliae } & S & $1300 f$ & $83 d$ & $11 \mathrm{ef}$ & 20de & $42 \mathrm{~cd}$ \\
\hline & $S / 2$ & 2000de & $128 \mathrm{c}$ & 14de & $21 d$ & 39de \\
\hline & $S / 4$ & $2700 c$ & $150 \mathrm{~b}$ & $20 \mathrm{~b}$ & $32 b$ & $35 e$ \\
\hline \multirow[t]{3}{*}{ Paecilomyces lilacinus } & S & $1500 \mathrm{ef}$ & $60 e$ & $6 g$ & $15 e$ & $47 a b c$ \\
\hline & $S / 2$ & $2500 \mathrm{~cd}$ & $80 d$ & $10 f$ & 17de & $44 \mathrm{bcd}$ \\
\hline & $S / 4$ & $4200 \mathrm{~b}$ & $80 d$ & $15 \mathrm{~cd}$ & 20de & 38de \\
\hline Untreated (control) & - & 11,000a & $350 a$ & $38 a$ & $66 a$ & $29 f$ \\
\hline
\end{tabular}

Means followed by different letter(s) are significantly different at $P \leq 0.05$

\section{Effect of the tested fungal culture filtrates on cowpea plant growth and yield}

Concerning cowpea plant growth, a significant augmentation of shoot length and fresh and dry weights and root fresh and dry weights and number and weight of pods as influenced by the tested filtrates of $B$. bassiana, M. anisopliae, and P. lilicanus were illustrated in Table 6 . The treatments significantly promoted plant growth and yield criteria and these increases were positively proportional to the filtrate dilution higher than the untreated plants. These treatments can be ranked in descending order as follows: $M$. anisopliae $>$ P. lilacinus $>B$. bassiana $>$ as they achieved the highest mean percentages of increases of plant growth and yield by $68.5,66.0$, and $48.0 \%$, respectively at the highest dilution compared to other treatments and untreated check. As for weight of pods, its highest increase was achieved by P. lilicanus (86.2\%) followed by $M$. anisopliae (55.2\%). Other treatments differed in their responses according to fungus and dilution tested. The least plant growth and yield increases were recorded by the least dilution (Table 7).

Effect of the tested fungal spores on root-knot nematode Tables 8 and 9 show that three conidial spore concentrations from B. bassiana, M. anisopliae, and P. lilacinus

Table 5 Percentages of reduction of number of the root-knot nematode, Meloidogyne incognita infecting cowpea, number of galls and percentages of increase in number of bacterial nodules as affected by three culture filtrates from Beauveria bassiana, Metarhiziam aniisopliae, and Paecilomyces lilacinus

\begin{tabular}{|c|c|c|c|c|c|c|c|}
\hline \multirow[t]{2}{*}{ Treatments } & \multirow[t]{2}{*}{ Dilution } & \multicolumn{3}{|c|}{$\%$ reductions in no. of nematodes } & \multirow{2}{*}{$\begin{array}{l}\% \text { mean } \\
\text { total } \\
\text { percentages } \\
\text { nematode } \\
\text { reduction }\end{array}$} & \multirow{2}{*}{$\begin{array}{l}\% \\
\text { reduction } \\
\text { in no. of } \\
\text { galls }\end{array}$} & \multirow{2}{*}{$\begin{array}{l}\% \\
\text { increases } \\
\text { in no. of } \\
\text { bacterial } \\
\text { nodules }\end{array}$} \\
\hline & & $\mathrm{J}_{2} \mathrm{~S}$ in soil & $\mathrm{J}_{2} \mathrm{~S}$ in roots & Egg masses & & & \\
\hline \multirow[t]{3}{*}{ Beauveria bassiana } & S & 86.4 & 85.7 & 71.1 & 81.1 & 75.8 & 72.4 \\
\hline & $S / 2$ & 80.0 & 82.9 & 65.8 & 76.2 & 72.7 & 65.5 \\
\hline & $S / 4$ & 63.6 & 68.8 & 52.6 & 61.7 & 60.6 & 24.1 \\
\hline \multirow[t]{3}{*}{ Metarhiziam aniisopliae } & S & 88.2 & 76.3 & 71.1 & 78.5 & 69.7 & 44.8 \\
\hline & $S / 2$ & 81.8 & 63.4 & 63.2 & 69.5 & 68.2 & 34.5 \\
\hline & $S / 4$ & 75.5 & 57.1 & 47.4 & 60.0 & 51.5 & 17.1 \\
\hline \multirow[t]{3}{*}{ Paecilomyces lilacinus } & S & 86.4 & 82.9 & 84.2 & 84.5 & 77.3 & 62.1 \\
\hline & $\mathrm{S} / 2$ & 77.3 & 77.1 & 73.7 & 76.0 & 74.2 & 51.7 \\
\hline & $S / 4$ & 61.8 & 77.1 & 60.5 & 66.5 & 69.7 & 31.0 \\
\hline Untreated (control) & - & 00.0 & 00.0 & 00.0 & 00.0 & 00.0 & 00.0 \\
\hline
\end{tabular}


Table 6 Number of root-knot nematode, Meloidogyne incognita infecting cowpea, number of galls and number of nodules as affected by three spore concentrations from Beauveria bassiana, Metarhiziam aniisopliae, and Paecilomyces lilacinus

\begin{tabular}{|c|c|c|c|c|c|c|}
\hline \multirow[t]{2}{*}{ Treatments } & \multirow[t]{2}{*}{ Dilution } & \multicolumn{3}{|c|}{ Mean no. of reproductive parameters of nematode } & \multirow{2}{*}{$\begin{array}{l}\text { Mean } \\
\text { No. of } \\
\text { galls/ } \\
\text { root } \\
\text { system }\end{array}$} & \multirow{2}{*}{$\begin{array}{l}\text { Mean } \\
\text { no. of } \\
\text { nodules/ } \\
\text { root } \\
\text { system }\end{array}$} \\
\hline & & $\mathrm{J}_{2} \mathrm{~s}$ in soil/pot & $\mathrm{J}_{2} \mathrm{~S}$ in roots/root system & Egg masses/root system & & \\
\hline \multirow[t]{3}{*}{ Beauveria bassiana } & $1 \times 10^{8}$ & $1000 \mathrm{~g}$ & $98 c d e$ & $12 \mathrm{bc}$ & $22 \mathrm{bc}$ & 35de \\
\hline & $1 \times 10^{7}$ & $2500 d$ & $113 \mathrm{bc}$ & $15 b$ & $24 b$ & $33 \mathrm{de}$ \\
\hline & $1 \times 10^{6}$ & $4050 b$ & $120 \mathrm{~b}$ & $16 b$ & $27 b$ & 32de \\
\hline \multirow[t]{3}{*}{ Metarhiziam aniisopliae } & $1 \times 10^{8}$ & $800 \mathrm{~h}$ & $55 \mathrm{~g}$ & $10 \mathrm{~cd}$ & $17 \mathrm{~cd}$ & $50 a$ \\
\hline & $1 \times 10^{7}$ & $2200 e$ & $75 f$ & $13 \mathrm{bc}$ & $18 \mathrm{~cd}$ & $46 a b$ \\
\hline & $1 \times 10^{6}$ & $3500 c$ & $75 f$ & $15 b$ & $25 b$ & 34de \\
\hline \multirow[t]{3}{*}{ Paecilomyces lilacinus } & $1 \times 10^{8}$ & $500 i$ & $83 e f$ & $6 d$ & $11 e$ & $44 a b c$ \\
\hline & $1 \times 10^{7}$ & $600 i$ & 90def & $7 d$ & 15de & $39 \mathrm{bcd}$ \\
\hline & $1 \times 10^{6}$ & $1750 f$ & $105 \mathrm{bcd}$ & $12 \mathrm{bc}$ & $22 b c$ & $35 \mathrm{de}$ \\
\hline Untreated (control) & - & $11000 a$ & $350 a$ & $38 a$ & $66 a$ & $29 e$ \\
\hline
\end{tabular}

Means followed by different letter(s) are significantly different at $P \leq 0.05$

were selected for their efficacy to control $M$. incognita infecting cowpea plant. Numbers of nematode juveniles in soil and roots, egg masses, as well as number of galls in roots and number of bacterial nodules were used as indicators for the efficacy of the tested fungi compared to untreated check. Table 6 illustrates mean numbers of treatments and untreated check. In general, on the basis of mean total percentages nematode reduction, data in Table 7 indicate that all chosen fungal spore concentrations had significantly suppressed the previous criteria according to fungal hypha and spore concentrations compared to untreated check. The overtopped significant results were gained with $P$. lilicanus at the highest spore concentration $\left(1 \times 8^{8}\right)$ which recorded the highest mean nematode reduction( $85.3 \%$ ) followed by $83.5 \%$ at medium concentration $\left(1 \times 8^{7}\right)$ of spore concentration with the highest mean reduction of number of egg masses (84.2\%) and $\mathrm{J}_{2}$ in soil (96.5\%). The second rank was obtained by $M$. anisopliae where it reduced all nematode numbers as a mean of $83.6 \%$ at the highest spore concentration and with the highest percentage reduction of number of juveniles in roots $(84.3 \%$.) at the same spore concentration. B. bassiana caused $77.1 \%$ as a mean percentage of nematode reduction at the highest spore concentration followed by other concentrations and untreated check.

Table 7 Percentages of reduction of number of the root-knot nematode, Meloidogyne incognita infecting cowpea, number of galls and percentages of increase of number of nodules as affected by three spore concentrations from Beauveria bassiana, Metarhiziam aniisopliae, and Paecilomyces lilacinus

\begin{tabular}{|c|c|c|c|c|c|c|c|}
\hline \multirow[t]{2}{*}{ Treatments } & \multirow[t]{2}{*}{ Concentration } & \multicolumn{3}{|c|}{$\%$ reduction in no. of nematodes } & \multirow{2}{*}{$\begin{array}{l}\% \text { mean } \\
\text { total } \\
\text { percentages } \\
\text { of } \\
\text { nematode } \\
\text { reduction }\end{array}$} & \multirow{2}{*}{$\begin{array}{l}\% \\
\text { reduction } \\
\text { in no. of } \\
\text { galls }\end{array}$} & \multirow{2}{*}{$\begin{array}{l}\% \\
\text { increase } \\
\text { in no. of } \\
\text { nodules }\end{array}$} \\
\hline & & $\mathrm{J}_{2} \mathrm{~s}$ in soil & $\mathrm{J}_{2} \mathrm{~s}$ in roots & $\overline{\text { Egg masses }}$ & & & \\
\hline \multirow[t]{3}{*}{ Beauveria bassiana } & $1 \times 10^{8}$ & 90.9 & 72.0 & 68.4 & 77.1 & 66.7 & 20.7 \\
\hline & $1 \times 10^{7}$ & 77.3 & 67.7 & 60.5 & 68.5 & 63.6 & 13.8 \\
\hline & $1 \times 10^{6}$ & 63.2 & 65.7 & 33.3 & 63.1 & 59.1 & 10.3 \\
\hline \multirow[t]{3}{*}{ Metarhiziam aniisopliae } & $1 \times 10^{8}$ & 92.7 & 84.3 & 73.7 & 83.6 & 74.2 & 72.4 \\
\hline & $1 \times 10^{7}$ & 80.0 & 78.6 & 65.8 & 74.8 & 72.7 & 58.6 \\
\hline & $1 \times 10^{6}$ & 68.1 & 78.6 & 60.5 & 69.1 & 62.1 & 17.2 \\
\hline \multirow[t]{3}{*}{ Paecilomyces lilacinus } & $1 \times 10^{8}$ & 95.5 & 76.3 & 84.2 & 85.3 & 83.3 & 51.7 \\
\hline & $1 \times 10^{7}$ & 94.5 & 74.3 & 81.6 & 83.5 & 77.3 & 34.5 \\
\hline & $1 \times 10^{6}$ & 84.1 & 70.0 & 68.4 & 74.1 & 66.7 & 20.7 \\
\hline Untreated (control) & - & 00.0 & 00.0 & 00.0 & 00.0 & 00.0 & 00.0 \\
\hline
\end{tabular}


Table 8 Effect of three fungal filtrates from Beauveria bassiana, Metarhiziam aniisopliae, and Paecilomyces lilacinus on vegetative parameters and yield of cowpea infected by root-knot nematode, Meloidogyne incognita

\begin{tabular}{|c|c|c|c|c|c|c|c|c|}
\hline \multirow[t]{2}{*}{ Treatments } & \multirow[t]{2}{*}{ Dilution } & \multicolumn{3}{|c|}{ Shoot parameters } & \multicolumn{2}{|l|}{ Root parameters } & \multicolumn{2}{|c|}{ Pod parameters } \\
\hline & & Length $(\mathrm{cm})$ & Fresh weight (g) & Dry weight (g) & Fresh weight (g) & Dry weight (g) & No. & Weight (g) \\
\hline \multirow[t]{3}{*}{ Beauveria bassiana } & $S$ & $54.3 c$ & $58.4 b$ & $11.6 \mathrm{c}$ & $9.5 a b$ & $2.7 a b$ & $4 a b$ & 3.8de \\
\hline & $\mathrm{S} / 2$ & $54.2 \mathrm{C}$ & $55.6 c$ & $11.4 \mathrm{C}$ & $7.1 \mathrm{c}$ & $2.6 a b c$ & $4 a b$ & $3.1 f$ \\
\hline & $S / 4$ & $50.3 c$ & $50.9 e$ & $10.0 d$ & $6.8 c$ & $2.4 \mathrm{bc}$ & $3 b$ & $3.0 f$ \\
\hline \multirow[t]{3}{*}{ Metarhiziam aniisopliae } & S & $57.5 a b$ & $62.1 \mathrm{a}$ & $13.6 b$ & $10.7 \mathrm{a}$ & $3.0 \mathrm{a}$ & $5 a$ & $4.5 b$ \\
\hline & $\mathrm{S} / 2$ & $57.0 b$ & $58.9 b$ & $13.3 b$ & $8.9 b$ & $2.8 a b$ & $5 a$ & $4.4 \mathrm{bc}$ \\
\hline & $S / 4$ & $52.0 d$ & $54.1 \mathrm{~d}$ & $9.2 d$ & $6.6 c$ & $2.6 a b c$ & $4 a b$ & $3.9 \mathrm{cde}$ \\
\hline \multirow[t]{3}{*}{ Paecilomyces lilacinus } & S & $58.8 \mathrm{a}$ & $61.4 \mathrm{a}$ & $16.3 a$ & $7.8 \mathrm{bc}$ & $3.0 \mathrm{a}$ & $5 a$ & $5.4 a$ \\
\hline & $\mathrm{S} / 2$ & $52.7 d$ & $55.7 \mathrm{c}$ & $14.2 \mathrm{~b}$ & $7.0 \mathrm{c}$ & $2.4 \mathrm{bc}$ & $4 a b$ & $4.3 \mathrm{bcd}$ \\
\hline & $\mathrm{S} / 4$ & $52.2 \mathrm{~d}$ & $48.2 f$ & $10.2 d$ & $6.8 c$ & $2.1 \mathrm{~cd}$ & $4 a b$ & $3.6 \mathrm{e}$ \\
\hline Untreated (control) & - & $46.3 f$ & $39.2 \mathrm{~g}$ & 7.0e & $5.0 \mathrm{~d}$ & $1.8 \mathrm{~d}$ & $3 b$ & $2.9 f$ \\
\hline
\end{tabular}

Means followed by different letter(s) are significantly different at $P \leq 0.05$

Also, the percentages of reduction of galls were significantly reduced by $83.3 \%$ caused by $P$. lilacinus at the highest spore concentrations followed by $77.3 \%$ caused by the same fungus at the medium spore concentration. $M$. anisopliae recorded reduction (74.2\%) and B. bassiana $(66.7 \%)$ at the highest concentration of spores compared to other treatments. On the other hand, control treatment (untreated infected plants) registered the highest numbers of reproductive parameters and galls of root knot nematode.

Number of bacterial nodules significantly increased by $72.4 \%$ caused by $M$. aniisopliae at the highest spore concentration followed by $58.6 \%$ at medium concentration. P. lilacinus recorded $51.7 \%$ increase in the number of bacterial nodules, while $B$. bassiana and other concentrations registered the least ones.

\section{Effect of the tested fungal spores on cowpea plant growth and yield}

Concerning cowpea plant growth, a significant augmentation of shoot length, fresh and dry weights, root fresh and dry weights, and number and weight of pods as influenced by the tested fungal spore concentrations of $B$. bassiana, M. anisopliae, and P. lilicanus was illustrated in Table 10. The treatments significantly promoted plant growth and yield criteria than the untreated plants and these increases were positively proportional to the concentration of spores. These treatments can be ranked in

Table 9 Percentages of increase of vegetative parameters and yield of cowpea infected by root-knot nematode, Meloidogyne incognita, as affected by three fungal filtrates from Beauveria bassiana, Metarhiziam aniisopliae, and Paecilomyces lilacinus

\begin{tabular}{|c|c|c|c|c|c|c|c|c|c|}
\hline \multirow[t]{2}{*}{ Treatments } & \multirow[t]{2}{*}{ Dilution } & \multicolumn{3}{|c|}{$\%$ shoot parameter increases } & \multicolumn{2}{|c|}{$\%$ root weight parameter increases } & \multicolumn{2}{|c|}{$\%$ pod parameter increases } & \multirow[b]{2}{*}{$\begin{array}{l}\% \text { mean } \\
\text { total } \\
\text { percentages } \\
\text { of plant } \\
\text { growth and } \\
\text { yield } \\
\text { increases }\end{array}$} \\
\hline & & Length & Fresh weight & Dry Weight & Fresh & Dry & No. & Weight & \\
\hline \multirow[t]{3}{*}{ Beauveria bassiana } & S & 17.3 & 49.0 & 65.7 & 90.0 & 50.0 & 33.3 & 31.0 & 48.0 \\
\hline & $\mathrm{S} / 2$ & 17.1 & 41.8 & 62.9 & 42.0 & 44.4 & 33.3 & 7.0 & 34.5 \\
\hline & $\mathrm{S} / 4$ & 9.6 & 29.8 & 42.9 & 36.0 & 33.3 & 00.0 & 3.0 & 22.1 \\
\hline \multirow[t]{3}{*}{ Metarhiziam aniisopliae } & $S$ & 24.1 & 58.4 & 94.3 & 114.0 & 66.7 & 66.7 & 55.2 & 68.5 \\
\hline & $\mathrm{S} / 2$ & 23.1 & 50.3 & 90.0 & 78.0 & 55.6 & 66.7 & 51.7 & 59.3 \\
\hline & $S / 4$ & 12.3 & 38.0 & 31.4 & 32.0 & 44.4 & 33.3 & 33.3 & 36.4 \\
\hline \multirow[t]{3}{*}{ Paecilomyces lilacinus } & $S$ & 27.0 & 56.6 & 103.0 & 56.0 & 66.7 & 66.7 & 86.2 & 66.0 \\
\hline & $\mathrm{S} / 2$ & 13.8 & 42.1 & 102.8 & 40.0 & 33.3 & 33.3 & 48.3 & 44.8 \\
\hline & $S / 4$ & 12.7 & 23.0 & 45.7 & 36.0 & 16.7 & 33.3 & 24.1 & 27.4 \\
\hline Untreated (control) & - & 00.0 & 00.0 & 00.0 & 00.0 & 00.0 & 00.0 & 00.0 & 00.0 \\
\hline
\end{tabular}


Table 10 Effect of three spore concentrations from Beauveria bassiana, Metarhiziam aniisopliae, and Paecilomyces lilacinus on vegetative parameters and yield of cowpea infected by root-knot nematode, Meloidogyne incognita

\begin{tabular}{|c|c|c|c|c|c|c|c|c|}
\hline \multirow[t]{2}{*}{ Treatments } & \multirow[t]{2}{*}{ Concentration } & \multicolumn{3}{|c|}{ Shoot parameters } & \multicolumn{2}{|l|}{ Root parameters } & \multicolumn{2}{|c|}{ Pod parameters } \\
\hline & & Length $(\mathrm{cm})$ & Fresh weight (g) & Dry weight (g) & Fresh weight (g) & Dry weight (g) & No. & $\begin{array}{l}\text { Weight } \\
\text { (g) }\end{array}$ \\
\hline \multirow[t]{3}{*}{ Beauveria bassiana } & $1 \times 10^{8}$ & $59.0 b$ & $63.8 b$ & $11.9 \mathrm{c}$ & $8.9 b$ & $3.2 \mathrm{a}$ & $5 a$ & $4.9 a$ \\
\hline & $1 \times 10^{7}$ & $48.0 f$ & 44.7e & $9.7 f$ & $8.6 b$ & $2.7 b c$ & $4 a b$ & $3.8 \mathrm{c}$ \\
\hline & $1 \times 10^{6}$ & $47.7 f$ & $42.8 f$ & $7.9 \mathrm{~h}$ & $6.9 \mathrm{ef}$ & $2.5 \mathrm{~cd}$ & $3 b$ & $3.1 \mathrm{de}$ \\
\hline \multirow[t]{3}{*}{ Metarhiziam aniisopliae } & $1 \times 10^{8}$ & $55.3 c$ & $64.8 b$ & $13.1 b$ & $10.8 \mathrm{a}$ & $2.9 \mathrm{~b}$ & $4 a b$ & $4.5 b$ \\
\hline & $1 \times 10^{7}$ & $52.8 d$ & $56.9 c$ & $11.1 d$ & $7.9 \mathrm{c}$ & $2.6 c$ & $3 b$ & $3.8 c$ \\
\hline & $1 \times 10^{6}$ & $50.1 e$ & $50.5 d$ & $10.1 \mathrm{e}$ & $7.3 \mathrm{~d}$ & $2.5 \mathrm{~cd}$ & $3 b$ & $3.3 d$ \\
\hline \multirow[t]{3}{*}{ Paecilomyces lilacinus } & $1 \times 10^{8}$ & $62.0 \mathrm{a}$ & $79.6 a$ & 17.1a & 7.2de & $2.5 \mathrm{~cd}$ & $5 a$ & $4.5 b$ \\
\hline & $1 \times 10^{7}$ & $54.5 c$ & $50.9 d$ & $10.1 \mathrm{e}$ & $6.8 f$ & $2.4 \mathrm{~cd}$ & $4 a b$ & $3.9 c$ \\
\hline & $1 \times 10^{6}$ & $50.3 e$ & $50.0 d$ & $8.5 \mathrm{~g}$ & $5.8 \mathrm{~g}$ & $2.2 d$ & $3 b$ & $3.1 \mathrm{de}$ \\
\hline Untreated (control) & - & $46.3 f$ & $39.2 \mathrm{~g}$ & $7.0 \mathrm{i}$ & $5.0 \mathrm{~h}$ & $1.8 \mathrm{e}$ & $3 b$ & $2.9 \mathrm{e}$ \\
\hline
\end{tabular}

Means followed by different letter(s) are significantly different at $P \leq 0.05$

descending order as follows: B. bassiana $>$ P. lilacinus $>$ $M$. anisopliae as they achieved the highest mean increases of plant growth and yield by $64.5,63.7 \%$, and $62.5 \%$, respectively at the highest spore concentration compared to other treatments and untreated check. As for weight of pods, its highest increase was achieved by B. bassiana (69.0\%) > each of P. lilacinus and M. anisopliae $(55.2 \%)$ at the highest spore concentration. Other treatments differed in their responses according to fungus and dilution tested. The least percentage of plant growth and yield increase was recorded by the least spore concentration (Table 11).

\section{Discussion}

Bioassay tests proved that the tested fungi either as filtrate or spore affected egg hatching and survival of second stage juveniles at different degrees according to fungal filtrate dilution, spore concentration, and exposure period. The percentages of juvenile mortality and egg inhibition of root-knot nematode were directly proportional with the concentration of culture filtrates of $B$. bassiana which agree with (Zhao et al. 2013). These effects on nematodes may refer to mode of action of $M$. anisopliae conidial spores as they attach to nematode cuticle, germinate, parasitize, directly penetrate, and produce the infective hyphae inside the nematode body as reported by Ghayedi and Abdollahi (2013). Also, some cyclopeptides and destruxins were produced by fungus which may play an important role in its pathogenicity (Kershaw et al. 1999). In accordance, nematode egg hatching inhibition and $\mathrm{J}_{2}$ mortality of the spore's suspension of $P$. lilacinus produced variable effects on rootknot nematode. The fungus caused $94 \%$ reduction in $M$. javanica egg hatching, especially at high concentration of $P$. lilacinus spore's suspension (3000 spores/ml) after
$48 \mathrm{~h}$ and also killed $57 \%$ of $M$. javanica juveniles $\left(\mathrm{J}_{2}\right)$ after $72 \mathrm{~h}$ as shown by Al Ajrami (2016).

The present results showed that fungal culture filtrates and spores of B. bassiana, M. anisopliae, and P. lilacinus under screen house conditions can significantly reduce nematode reproductive parameters and improve the growth and yield of cowpea plants as well. The effect of Beauveria may due to that it can produce beauvericin and oosporin as beauvericin has an activity against $M$. incognita (Hamil et al. 1969; Suzuki et al. 1977; Anke et al. 1995). The mode of action of P. lilacinus against plant parasitic nematodes was explained by many investigations as follows: directed penetration of fungal hyphae to the female cuticle of $M$. javanica as reported by Khan et al. (2006). Whereas, Park et al. (2004) reported that $P$. lilacinus could produce leucino toxin and other nematicidal compounds, destroying the egg embryos of M. incognita within 5 days because of simple penetration of the egg cuticle by individual hypha. This may be due to mechanical and/or enzymatic activities resulting in killing juveniles and females of M. incognita and Globodera pallida (Jatala 1986), deformed eggs in M. incognita never matured or hatched (Jatala 1985) and penetration of the fungus through the egg shell of the nematode by serine protease produced by $P$. lilacinus (Bonants et al. 1995; Khan et al. 2004).

The significant results in most cases by using the tested fungi in the present study indicate their higher efficacy as promising bioagents on root-knot nematode and consequently on plant growth and yield of cowpea plants, one of the most important leguminous crops in Egypt.

Our results on using the tested fungi for nematode control can be generalized and carried out on a field scale for controlling root-knot nematode in Egypt. This 
Table 11 Percentages of increase of vegetative parameters and yield of cowpea infected by root-knot nematode, Meloidogyne incognita, as affected by three spore concentrations from Beauveria bassiana, Metarhiziam aniisopliae, and Paecilomyces lilacinus

\begin{tabular}{|c|c|c|c|c|c|c|c|c|c|}
\hline \multirow[t]{2}{*}{ Treatments } & \multirow[t]{2}{*}{ Concentration } & \multicolumn{3}{|c|}{$\%$ increases in shoot parameters } & \multicolumn{2}{|c|}{$\begin{array}{l}\% \text { increases in root } \\
\text { parameters }\end{array}$} & \multicolumn{2}{|c|}{$\begin{array}{l}\% \text { increases in pod } \\
\text { parameters }\end{array}$} & \multirow{2}{*}{$\begin{array}{l}\% \text { mean } \\
\text { total } \\
\text { percentages } \\
\text { of plant } \\
\text { growth and } \\
\text { yield } \\
\text { increases }\end{array}$} \\
\hline & & Length & Fresh weight & Dry weight & Fresh weight & Dry weight & No. & Weight & \\
\hline \multirow[t]{3}{*}{ Beauveria bassiana } & $1 \times 10^{8}$ & 27.4 & 62.8 & 70.0 & 78.0 & 77.8 & 66.7 & 69.0 & 64.5 \\
\hline & $1 \times 10^{7}$ & 4.0 & 14.0 & 38.6 & 72.0 & 50.0 & 33.3 & 31.0 & 34.7 \\
\hline & $1 \times 10^{6}$ & 3.0 & 9.2 & 12.9 & 38.0 & 38.9 & 00.0 & 7.0 & 15.6 \\
\hline \multirow{3}{*}{ Metarhiziam aniisopliae } & $1 \times 10^{8}$ & 19.4 & 65.3 & 87.1 & 116.0 & 61.1 & 33.3 & 55.2 & 62.5 \\
\hline & $1 \times 10^{7}$ & 14.0 & 45.2 & 58.6 & 58.0 & 44.4 & 00.0 & 31.0 & 35.9 \\
\hline & $1 \times 10^{6}$ & 8.2 & 28.8 & 44.3 & 46.0 & 38.9 & 00.0 & 13.8 & 25.7 \\
\hline \multirow[t]{3}{*}{ Paecilomyces lilacinus } & $1 \times 10^{8}$ & 33.9 & 103.1 & 104.4 & 44.0 & 38.9 & 66.7 & 55.2 & 63.7 \\
\hline & $1 \times 10^{7}$ & 17.7 & 29.8 & 44.3 & 36.0 & 33.3 & 33.3 & 34.5 & 32.7 \\
\hline & $1 \times 10^{6}$ & 8.6 & 27.6 & 21.4 & 16.0 & 22.2 & 00.0 & 7.0 & 14.7 \\
\hline Untreated (control) & - & 00.0 & 00.0 & 00.0 & 00.0 & 00.0 & 00.0 & 00.0 & 00.0 \\
\hline
\end{tabular}

can be done by producing higher quantities of biomasses from these biogents by rearing the tested fungi in pure cultures in the laboratory (Tawfiq 1997) and applied them in experiments in the field to explore and increase their effects on root-knot and the other most economically important nematodes. Khudhair et al. (2016) proved that B. Bassiana isolate (MARD 92) was identified to have endophytic property which enables it to be established within plant tissues and increases its field efficacy in controlling some pests.

\section{Conclusions}

It can be concluded that B. bassiana, M. Anisopliae, and $P$. lilacinus as antagonistic fungi proved to be efficient against root-knot nematode. These fungi reduced $M$. incognita infectivity which subsequently improved plant growth and yield. This effect may be due to either some toxic compounds secreted by the tested fungi or nematode egg deformation by $P$. lilacinus. These results are considered the first report in Egypt because of B. bassiana and M. Anisopliae were commonly used previously as bio-insecticides only against some insects, but were not used to control nematodes. Further studies are needed to explore the most efficient method by these two bioagents for controlling root-knot nematode on a field scale in different crops.

\section{Abbreviations}

ANOVA: Analysis of variance; COSTAT: Computer Statistical Package; $S$ : Standard; $J_{2}$ : Second stage juveniles; $M$ : The percentages non-hatched eggs or dead juveniles in the treatment; $n$ : The percentages non-hatched eggs or dead juveniles in the control
Authors' contributions

MMAY suggested the idea and problem, participated in the design of the study, wrote the manuscript, and helped in conducting the experimental work. WMAE carried out the most experimental work, performed statistical analysis, and drafted the manuscript. DEML provided with some literature papers related to the tested fungi, identified, and prepared the fungal extracts tested. All authors read and approved the final manuscript.

\section{Funding}

There is no funding.

\section{Availability of data and materials}

The tested fungi and nematodes are available in Egyptian environment and identified in the laboratory.

Ethics approval and consent to participate

Not applicable

Consent for publication

Not applicable

\section{Competing interests}

The authors declare that they have no competing interests.

\section{Author details}

${ }^{1}$ Department of Plant Pathology, Nematology Lab., National Research Centre, Dokki, Cairo 12622, Egypt. ${ }^{2}$ Cotton Leaf Worm Department, Plant Protection Research Institute, Agricultural Research Centre, Dokki, Giza, Egypt.

Received: 22 November 2019 Accepted: 18 June 2020

Published online: 03 July 2020

\section{References}

Abbott WS (1925) A method of computing the effectiveness of an insecticide. J Econ Entomol 18(2):265-267

Aboul-Eid HZ, Youssef MMA (1998) Evaluation of four potato cultivars against Meloidogyne incognita and Rotylenchulus reniformis in relation to nematode symptoms and biocontrol agents. Egypt J Agron 2:27-42

Al Ajrami HHM (2016). Evaluation the effect of Paecilomyces lilacinus as a biocontrol agent of Meloidogyne javanica on tomato in Gaza Strip.M.Sci.in Biological Sciences (Microbiology), Faculty of science, The Islamic UniversityGaza,63 pp. 
Anke H, Stadler M, Mayer A (1995) Secondary metabolites with nematicidal and antimicrobial activity from nematophagous fungi and ascomycetes. Can J Bot 72(SI):932-939

Barker TR (1985). Nematode extraction and bioassays. In: "An Advanced Treatise on Meloidogyne": Vol. II. Methodology (Barker TR, Carter CC, Sasser JN, eds.) North Carolina State University, USA, 19-35 pp.

Bekanayake HMRK, Jayasundar NJ (1994) Effect of Paecilomyces lilacinus and Beauveria bassiana in controlling Meloidogyne incognita on tomato in Sri Lanka. Nematol Mediterr 22(1):87-88

Bonants PJ, Fitters PF, Thijs H, den Belder E, Waalwijk C, Henfling JWD (1995) A basic serine protease from Paecilomyces lilacinus with biological activity against Meloidogyne hapla eggs. Microbiology 141(4):775-784

Caroppo S, Perito B, Pelagatti O (1990) In vitro evaluation of nematicide activity by several fungi against Meloidogyne incognita eggs. Redia 73:451-462

Cayrol JC, Dijan C, Pijarowski L (1989) Study of the nematocidal properties of the culture filtrate of the nematophagous fungus Paecilomyces lilacinus. Rev Nematol 12(4):331-336

Cayrol JC, Dijan-Caporalino C, Panchaud-Mattei E (1992) La lutte biologique contre les nématodes phytoparasites. Courrier de la cellule Environnement de I'INRA 17:31-44

Chen SY, Dickson DW, Mitchell DJ (1996) Pathogenicity of fungi to eggs of Heterodera glycines. J Nematol 28(2):148-158

Ciancio A (1995) Observations on the nematicidal properties of some mycotoxins. Fundam Appl Nematol 18(5):451-454

Ghayedi S, Abdollahi M (2013) Biocontrol potential of Metarhizium anisopliae (Hypocreales: Clavicipitaceae), isolated from suppressive soils of BoyerAhmad region, Iran, against $\mathrm{J}_{2} \mathrm{~s}$ of Heterodera avenae. J Plant Prot Res 53(2): 165-171

Goswami BK, Mittal A (2004) Management of root-knot nematode infecting tomato by Trichoderma viride and Paecilomyces lilacinus. Ind Phytopathol 57(2):235-236

Goswami BK, Pandey RK, Rathour KS, Bhattacharya C, Singh L (2006) Integrated application of some compatible biocontrol agents along with mustard oil seed cake and furadan on Meloidogyne incognita infecting tomato plants. J Zhejiang Univ Sci B 7(11):873-875

Hamil PL, Higgens CE, Boaz HE, Gorman M (1969) The structure of Beauvericin, A new depsipepdicle antibiotic toxic to Artemia salina. Tetrahedron Lett 10(49): 4255-4258

Haseeb A, Kumar V (2006) Management of Meloidogyne incognita-Fusarium solani disease complex in brinjal by biological control agents and organic additives. Ann Plant Prot Sci 14(2):519-521

Hussey RS, Barker KR (1973) A comparison of methods of collecting inoculation of Meloidogyne species, including a new technique. Plant Dis 57:1025-1028

Jahanbazian L, Abdollahi, M, Hussienvand M (2014). Inhibitory effect of Metarhizium anisopliae against Meloidogyne incognita, the causal agent of root knot of tomato, under laboratory condition. National Conference of Modern Topic in Agriculture. March 6, Tehran, Iran.

Jahanbazian L, Abdollahi M, Rezaie R (2015) Combined effect of Metarhizium anisopliae and Pseudomonas fluorescens CHAO on root-knot nematode, Meloidogyne incognita in tomato. Iranian J Plant Pathol 51(3):339-355

Jatala P (1985). Biological control nematodes. In: An Advanced Treatise on Meloidogyne -Biology and Control. Sasser J.N, Carter CC (Eds) Vol.1, North Carolina State University, Graphics, pp.303-308.

Jatala P (1986) Biological control of nematodes. Annu Rev Phytopathol 24:453-489

Kerry BR (2000) Rhizosphere interactions and the exploitation of microbial agents for the biological control of plant-parasitic nematodes. Annu Rev Phytopathol 38:423-441

Kershaw MJ, Moorhouse ER, Bateman R, Reynolds SE, Charnley AK (1999) The role of destruxins in the pathogenicity of Metarhizium anisopliae for three species of insect. J Invertebr Pathol 74(3):213-223

Khan A, Williams KL, Nevalainen HK (2004) Effects of Paecilomyces lilacinus protease and chitinase on the eggshell structures and hatching of Meloidogyne javanica juveniles. BioControl 31(3):346-352

Khan A, Williams KL, Nevalainen HK (2006) Infection of plant-parasitic nematodes by Paecilomyces lilacinus and Monacrosporium lysipagum. BioControl 51(5): 659-678

Khosrawi M, Abdollahi M, Sadravi M (2014) Effect of Metarhizium anisopliae and Trichoderma harzianum on root knot nematode, Meloidogyne javanica. Biol Control Pests Plant Dis 3(1):67-76

Khudhair MW, Alrubeai HF, Khalaf ZM (2016) Innovative method to control Dubas Bug, Ommatissus lybicus (Deberg) (Homoptera: Tropiduchidae) in date palm orchards using endophytic Beauveria bassiana isolates. J Agric Sci Technol A 6:394-402

Liu T, Wang L, Duan YX, Wang X (2008) Nematicidal activity of culture filtrate of Beauveria bassiana against Meloidogyne hapla. World J Microbiol Biotechnol 24(1):113-118

Mokhtari S, Sahebani N, Etebarian HR (2009) Study on biological control and systemic induction of peroxidase enzyme activity in tomato plant infected with root-knot nematode (Meloidogyne javanica) by Pseudomonas fluorescens CHA0 antagonist. J Agric For 11(1):151-161

Park JO, Hargreaves J, McConville E, Stirling G, Ghisalberti E, Sivasithamparam K (2004) Production of leucinostatins and nematicidal activity of Australian isolates of Paecilomyces lilacinus (Thom) Samson. Lett Appl Microbiol 38(4): $271-276$

Sabouraud R (1892) Contribution a l'etude de la trichophytie humaine. Etude clinique, microscopique et bacterioloqique sur la pluralité des trichophytons de l'homme. Ann Dermatol Syphil 3:1061-1087

Snedecor GW, Cochran WG (1989) Statistical Methods. 8th ed. lowa State University Press, Ames, lowa

Suzuki A, Kanaoka M, Isogai A (1977) Bassianolide, a new insecticidal cyclodepsipeptide from Beauveria bassiana and Verticillium lecanii. Tetrahedron Lett 25:2167-2170

Tawfiq MFS (1997) (Editor). Biological control in agricultural pests. Tab INC, 759 pp.

Taylor AL, Sasser JN (1978) Biology, identification and control of root-knot nematodes (Meloidogyne species). IMP, North Carolina State University Graphics, Raleigh (NC)

Tian B, Yang J, Zhang K (2007) Bacteria used in the biological control of plantparasitic nematodes: populations, mechanisms of action, and future prospects. FEMS Microbiol Ecol 61(2):197-213

Tribhuvaneshwar Sharma MK, Bhargava S (2008) Efficacy of green muscardine fungi, Metarhizium anisopliae against reniform nematode, Rotylenchulus reniformis on tomato. Ind J Nematol 38(2):242-244

Vianna F, Pelizza S, Russo L, Allegrucci N, Scorsetti A (2018) Endophytic Beauveria bassiana (Ascomycota: Hypocreales) alters Helicoverpa gelotopoeons (D.) (Lepidoptera: Noctuidae) life cycle and reproductive parameters. J Plant Prot Res 58(4):321-327

Young TW (1954) An incubation method for collecting migratory-endoparasitic nematodes. Plant Dis Rep 38(11):794-795

Zhao D, Liu B, Wang Y, Zhu X, Duan Y, Chen L (2013) Screening for nematicidal activities of Beauveria bassiana and associated fungus using culture filtrate. Afr J Microbiol Res 7(11):974-978

\section{Publisher's Note}

Springer Nature remains neutral with regard to jurisdictional claims in published maps and institutional affiliations.

\section{Submit your manuscript to a SpringerOpen ${ }^{\circ}$ journal and benefit from:}

- Convenient online submission

- Rigorous peer review

- Open access: articles freely available online

- High visibility within the field

- Retaining the copyright to your article

Submit your next manuscript at $>$ springeropen.com 